\title{
Teaching Computer Science and Information Technology Studies for students of musical and pedagogical specialties
}

\author{
Irina Borisovna Gorbunovaid \\ Herzen Russian State Pedagogical University, St. Petersburg, Russia \\ Anastasia Anatolyevna Pankovailio \\ Herzen Russian State Pedagogical University, St. Petersburg, Russia
}

\begin{abstract}
The processes of informatization transform the environment of professional activity of a contemporary music teacher, cause the formation of new educational needs of students of musical and pedagogical specialties, necessitate significant changes in the activities of a music teacher related to the creation and use of digital educational resources, the widespread introduction of techniques and methods of network interaction. Music Computer Technology allows for applying effectively the pedagogical experience of traditional music teaching and the new features of a modern musical computer.
\end{abstract}

\section{Keywords}

Information Technology in Education. Information competence. Music Computer Technologies. Computer musical creativity.

\section{Ensino de Ciência da Computação e Estudos de Tecnologia da Informação para alunos de especialidades musicais e pedagógicas}

\begin{abstract}
Resumo
Os processos de informatização transformam o ambiente de atividade profissional de um professor de música contemporânea, provocam a formação de novas necessidades educacionais de estudantes de especialidades musicais e pedagógicas, requerem mudanças significativas nas atividades de um professor de música relacionadas à criação e uso de recursos digitais educacionais, a introdução generalizada de técnicas e métodos de interação em rede. A Tecnologia do Computador Musical permite aplicar efetivamente a experiência pedagógica do ensino tradicional de música e os novos recursos de um computador musical moderno.
\end{abstract}

\section{Palavras-chave}

Tecnologia da informação na educação. Competência em informação. Tecnologias de computador para Música. Criatividade musical por computador. 


\title{
Docencia en Informática y Estudios de Tecnología de la Información para estudiantes de especialidades musicales y pedagógicas
}

\begin{abstract}
Resumen
Los procesos de informatización transforman el entorno de actividad profesional de un profesor de música contemporánea, provocan la formación de nuevas necesidades educativas de estudiantes de especialidades musicales y pedagógicas, requieren cambios significativos en las actividades de un profesor de música relacionadas con la creación y el uso de los recursos de educación digital, la introducción generalizada de técnicas y métodos de interacción de red. La Tecnología Informática de Música permite aplicar de manera efectiva la experiencia pedagógica de la enseñanza musical tradicional y las nuevas características de una computadora musical moderna.
\end{abstract}

\section{Palabras clave}

Tecnología de la Información en Educación. Competencia de información. Tecnologías Informáticas de Música. Creatividad musical informática.

\section{Introduction}

The era of information technology has a huge impact on the life of art: $99 \%$ of all new musical production in the world today is created and recorded using musical computer technologies (MCT) (GORBUNOVA, 2019), electronic musical instruments (GORBUNOVA, 2018a, 2018b) and music computers (MC). Electronic and computer music is becoming one of the most important components of modern musical culture. The electro-acoustic sound material is objectively the basis for updating musical art and musical culture as a whole: new expressive possibilities appear; new genres, styles arise, new artistic forms of expression and display of musical space open up, and much more.

\begin{abstract}
Music and art change, one might say, every fifty years. A human being is constantly experiencing new opportunities. [...] I am convinced that we are approaching the point of bifurcation, which is associated with progress in the development of information technologies and all that relates to them, such as the media, robotics and artificial intelligence. This is a networked society. (PRIGOGINE, 2000).
\end{abstract}

At present, computer science unites various spheres of human activity. Many scientists consider computer science as a new fundamental science, founded, as noted by Colin (2006), on:

[...] the recognition of the fundamental nature of the concept of information, which is the most important object of studying informatics as a fundamental science, as 
well as on the hypothesis according to which information laws should have a common basis for their manifestation, both in living and inanimate nature, including - and in technical systems artificially created by humans.

Today, Russian musicians know computer science and apply it in creative activities, as a rule, quite fragmentarily; musicians have little knowledge in computer science, which is though necessary to master modern MC and other information tools fully. As a result, they are often forced to work outside the global professional information environment in particular and the modern information society as a whole. Such isolation significantly reduces the list of means and methods of professional activity and the implementation of own creative projects and reduces the communicative capabilities of the teacher-musician. In order to solve this problem in particular, as well as with the goal of integrating Russia into the modern information society, significant changes are needed in the field of informatization of musical education.

\section{Literature review}

The authors have analyzed the methodological problems of teaching computer science and information technology (IT) to students of musical pedagogical specialties in Russian - Alieva, Gorbunova and Mezentseva (2019a); Belov and Gorbunova (2016); Gorbunova, Kameris and Bazhukova (2020); Gorbunova and Chibirev (2019); Gorbunova and Kibitkina (2010); Gorbunova and Petrova (2019); Gorbunova and Plotnikov (2019); Gorbunova and Zalivadny (2018); Gorbunova and Zalivadny (2019); Lozhakova (2012) and foreign universities - Alieva, Gorbunova and Mezentseva (2019b); Bello (2014); Chao-Fernández, R., Román-García and Chao-Fernández, A. (2017); Crawford and Southcott (2017); Erasmo (2015); Esperón (2018); Goh (2016); Gorbunova and Hiner (2019); Gorbunova and Kameris (2019); Hastings (2018); Nelia and Bean (2014); Permezel (2014); Sosnevas (2018); Wise (2016); Zhilyaeva (2014). Scientists and educators note that, despite the effectiveness and accessibility of digital technologies in the educational process (HORITA, 2014), MCT and music technologies in music education (KING; HIMONIDES; RUTHMANN, 2017), teachers remain conservative in their approaches to teaching musical disciplines, musical composition (WISE, 2016), in the real musical educational process, music education programs do not correlate with

Educ. Form., Fortaleza, v. 5, n. 3, p. 1-17, set./dez. 2020

DOI: https://doi.org/10.25053/redufor.v5i15set/dez.3350

https://revistas.uece.br/index.php/redufor/index 
teaching IT (CRAWFORD; SOUTHCOTT, 2017), although IT is quickly entering all professions, this process is much slower in the music field (CHAO-FERNÁNDEZ, R.; ROMÁN-GARCÍA; CHAO-FERNÁNDEZ, A., 2017). It was revealed that the effectiveness of education is achieved when new knowledge is acquired in the process of creative activity (BELOV; GORBUNOVA, 2016; GORBUNOVA, 2020; GORBUNOVA; PLOTNIKOV, 2019), when the educational activity is as close as possible to the professional activity of a musician, and new disciplines are studied in the context of the activity of a musician (BELOV; GORBUNOVA, 2016; GORBUNOVA; CHIBIREV, 2019). Given this, it is advisable to build a process of teaching computer science and its applied aspects for students - future music teachers - based on a contextual approach (GORBUNOVA; KIBITKINA, 2010; GORBUNOVA; PETROVA, 2019; GORBUNOVA; ZALIVADNY, 2018; RADIF; MOHAMMED, 2019; SERGEEVA et al., 2019). This approach allows for maximum bringing the content of information education to the creative professional activity of a musician, creates the conditions for a better understanding and effective assimilation of program material on computer science (COLIN, 2006; GORBUNOVA; KAMERIS; BAZHUKOVA, 2020; GORBUNOVA; ZALIVADNY, 2019; LOZHAKOVA, 2012), and contributes to the formation of the ability to independently use the acquired knowledge in musical, creative and teaching activities.

Thus, a requirement for the training of future musicians and especially musicians and teachers is the development of information competence (IC), which involves not only mastering the means of modern IT and ICT but also their application in solving various problems in the field of musical creativity, in including in the field of inclusive musical education (GORBUNOVA; GOVOROVA, 2018).

\section{Methodology}

Understanding the teaching of computer science in the system of modern musical and pedagogical education, the totality of various processes:

- Teaching basic general informatics and IT (for example, the discipline "Information Technology" (for undergraduate studies) and "Information Technology in Professional Activities" (for master's degrees) in the direction of 
"Pedagogical Education"), which is studied by future professionals in 1st-2nd years of the undergraduate courses);

- Applied IT education, which is usually studied by future music teacher in advanced courses;

- Computer science training at various levels (future bachelors, masters, specialists, graduate students).

The authors have developed a methodology for teaching computer science and IT for future music teachers, based on the introduction of a set of educational disciplines, which allows for creating a continuous and interdependent process of teaching IT to students.

The most effective teaching method in the implementation of the developed complex programs was the project method. Students' project activities allowed them to reveal the talents and creative potential of students, make each task personally meaningful for them, and increase their independence and activity. The creative project has a pronounced practical orientation, the ability to combine individual and collective types of work, apply various methods of activity and means of achieving the desired result.

The authors found that work on a creative project that has an interdisciplinary nature, when students have to search for the necessary information, analyze and systematize the knowledge gained, independently come to certain conclusions and generalizations, helps to improve computer science knowledge in students of musical and pedagogical specialties, and expands application skills modern IT, forms and develops the information competence (IC) of future music teachers, based on the active use of MCT.

The authors define the main stages of project activities:

\section{Problem-target.}

A topic is selected, similar projects are studied and it is determined how the result should look like. At this stage, the students are acquainted with the technology for creating the selected project, discussion, formulation of specific tasks, identification of information sources. 


\section{Development of the project structure.}

The structure of the project is determined; the students are divided into groups (if the project involves group execution). Also at this stage, students consult with teachers of related courses, clarify the plan of activities and the sequence of the project and approve the terms of the project.

\section{Implementation of the project.}

During this stage, practical work on a creative project takes place, the embodiment of what was conceived. As a rule, this stage is divided into composite thematic blocks consisting of creative tasks, the consistent implementation of which leads to the result - a creative project.

\section{Preliminary discussion of the results.}

Analysis of performed work achieved goals and results. Preview of the project. Planning to correct deficiencies, "work on mistakes".

\section{Critical review.}

The critical review is in the form of a public report, during which the results of project activities are presented and prospects for further improvement of this work and the possibility of using its results in further professional and educational activities are highlighted. Protection of a creative project allows you to evaluate the completeness and systematicity of knowledge, skills of students in using IT in working with musical material, with sound and multimedia, and special professional software. Evaluation criteria for each project may be different, but common are as follows: volume, completeness, completeness of development; ability to argue one's opinion; aesthetics of presenting the results of the work performed; the level of creative expression, artistic and aesthetic novelty and originality of presenting the topic. Project protection can also take place in the framework of competitions, academic concerts, conferences, including the use of IT by posting a completed project on websites and discussing it later on thematic forums.

In the process of mastering the course of the considered complex, students created creative projects of various levels: "microprojects" (within the framework of the covered topic: 1-2 lessons) and "macro projects", the work on which creation was carried out throughout the academic year or the semester. 


\section{Results and discussion}

The authors give examples of creative projects created in the process of teaching computer science by students - future music teachers - while mastering the disciplines of the developed complex.

The "Information Technology in Music" course. The introduction and widespread use of the possibilities of MCT in the study of this discipline allows students of musical and pedagogical specialties to better understand and study computer science, to master more methodological tools for the formation of an individual educational path and the implementation of pedagogical technologies using MCT in the future professional activity of a music teacher.

In the process of practical development of various topics, students carry out the corresponding educational tasks in the form of a creative project with the use of MCT. For example, when studying interactive technologies and three-dimensional visualization systems, students carry out a project to analyze musical information using various options for its two-and three-dimensional graphic display in the Sonic Visualiser program, use the Soundation online music sequencer, with which they create own creative musical projects.

In the course of laboratory work and creative projects in this discipline, students of musical and pedagogical specialties receive basic skills in working with the software and hardware of modern information technologies based on MCT, get acquainted with the hardware and software of a music computer, master the basic functionality and user interface of the following groups of application programs for computer musical creativity:

- Music and publishing programs (Sibelius, Final, etc.);

- Construction programs (GrooveMaker, FruityLoops, Dance Machine, Dance eJay, Hip-Hop eJay, etc.);

- Sequencer programs (Reaper, Soundation, Sonar);

- Auto-arranger programs (EasyKeys, Music Station, Band-in-a-Box, etc.);

- Audio editors (Sony Sound Forge, Samplitude Studio, WaveLab);

- Sound libraries, samplers, virtual synthesizers (Edirol Super Quartet, Edirol HQ Orchestral, Korg Wavestation, etc.);

- Software modules for audio processing (L3 MultiMaximizer, TrueVerb, etc.)

Educ. Form., Fortaleza, v. 5, n. 3, p. 1-17, set./dez. 2020

DOI: https://doi.org/10.25053/redufor.v5i15set/dez.3350

https://revistas.uece.br/index.php/redufor/index 
- Video editors TMPGEnc XPress, Sony Movies Studio Platinum;

- Screen video capture programs (Hyper Cam, Rylstim Screen Recorder, CamStudio);

- Programs for analyzing and displaying the contents of an audio file (Sonic Visualiser), etc.;

- Creating DVD, Blu-ray, etc. disks with built-in Windows OS tools.

At the final stage of the study of the course, the acquired skills are fixed during the implementation of creative projects in distance musical education systems (for example, the educational resource "Coursera" https://www.coursera.org).

In the process of working on creative projects, a variety of MCT software and hardware are used. The authors give an example of a creative educational project "Pictures at an Exhibition by M.P. Mussorgsky" (Table 1) in which students learn skills in audio, video and graphic editors (Sony Sound Forge, Sony Movies Studio Platinum, Adobe Photoshop) based on musical material. The results of the creative work are presented in the form of a multimedia presentation (ProShow Producer).

Table 1 - Creative project in the "Information Technology in Music" course

\begin{tabular}{|c|c|c|}
\hline $\mathrm{S} / \mathrm{N}$ & $\begin{array}{l}\text { Sections of the creative } \\
\text { educational project }\end{array}$ & $\begin{array}{c}\text { The content of the sections of the creative educational project "Pictures } \\
\text { at an Exhibition by M.P. Mussorgsky" }\end{array}$ \\
\hline 1. & $\begin{array}{l}\text { Preparation of } \\
\text { theoretical material }\end{array}$ & $\begin{array}{l}\text { The task is to prepare the theoretical material, which will include: } \\
\text { - Biographies of M.P. Mussorgsky, V. Hartmann; } \\
\text { - The story of the creation of the suite of pieces Pictures at an } \\
\text { Exhibition. Pictures at an Exhibition by Mussorgsky. Interesting facts } \\
\text { and events; } \\
\text { - Clearly illustrating audio, video, and musical examples (manuscript } \\
\text { fragments) of pieces, as well as examples of orchestral and non- } \\
\text { orchestral arrangements, quoting of individual pieces, theatrical } \\
\text { productions, cartoons and films using the series of pictures Pictures } \\
\text { at an Exhibition by Mussorgsky. }\end{array}$ \\
\hline 2. & $\begin{array}{l}\text { Recording own } \\
\text { performance of the work } \\
\text { of the selected composer }\end{array}$ & $\begin{array}{l}\text { Recording and subsequent processing of one's performance of one of } \\
\text { the of pieces Pictures at an Exhibition by Mussorgsky using an audio } \\
\text { editor (Sound Forge). }\end{array}$ \\
\hline 3. & Creating a presentation & $\begin{array}{l}\text { Processing collected material for inclusion in a presentation (ProShow } \\
\text { Producer). }\end{array}$ \\
\hline
\end{tabular}

Source: Own elaboration (2020).

Projects within the framework of the "Computer Technologies in Musical Education" course are the development of a multimedia textbook for conducting lessons in various musical disciplines (solfeggio, harmony, polyphony, music literature, etc.). For example, as part of the implementation of a creative macro project to create a multimedia 
textbook "Practical Solfeggio Course", each student performs a micro project to develop one of its sections ("Intervals", "Modes of Folk Music", "Tritons", etc.) (Table 2).

Table 2 - Creative project in the "Computer Technology in Musical Education" course

\begin{tabular}{|c|c|l|c|}
\hline $\mathrm{S} / \mathrm{N}$ & $\begin{array}{c}\text { Sections of the } \\
\text { creative micro- } \\
\text { project }\end{array}$ & The content of the sections within the creative microproject "Modes of Folk \\
Music"
\end{tabular}

Source: Own elaboration (2020).

As a result, the prepared thematic sections are combined into a single multimedia textbook, which can be used by future music teachers in professional activities.

Given that the set of disciplines, which the authors have developed, has a levelmodular structure, the ongoing projects also support this principle of building the educational process. This approach allows you to flexibly build projects from thematic blocks, integrate various types and forms of training, choose the most suitable ones for a particular group of students, who, in turn, get the opportunity to work independently with the proposed project at a pace convenient for them.

The construction of an individual learning path in computer science as part of a modular approach for students of musical and pedagogical specialties is effective because it allows for considering the specifics of the educational process, flexibly build content from blocks, and integrate various types and forms of training to implement the most effective educational paths of students.

Therefore, the "Computer Technologies in Musical Education" curriculum consists of thematic blocks, each of which involves the study of the theoretical section and the practical implementation of the project using the necessary IT and MCT tools. Such a construction of the educational process, in the authors' opinion, will prepare students not 
only for working with the studied software products, but also form a holistic view of modern IT and the possibilities of their application in professional activities.

In the learning process, students receive some tasks in the form of a set (case) of teaching materials for independent study and implementation of the corresponding project. Case technology allows for cultivating independence in solving future professional problems, including tasks that they have not previously encountered, case technologies also allow more efficient use of class time due to the effective organization of students' independent work.

The "Computer Music" course provides for increasing the IT of student musicians in the process of creating own musical and creative projects, as well as obtaining professional skills in modern IT and MCT in the field of sound engineering, computer musical creativity, sounding of films, performances, web sites, etc.

It should be noted that for the successful implementation of such a creative project, it is necessary to possess not only the basic skills in the field of IT and MCT but also the free use of musical knowledge (in the field of solfeggio, harmony, polyphony, instrumental studies, etc.).

Practical work on the creative project of the "Computer Music" course is divided into many thematic blocks, each of which, in turn, can be performed at a basic or advanced level of complexity (Table 3).

Table 3 - Creative project in the framework of the discipline "Computer Music"

\begin{tabular}{|c|c|c|}
\hline $\begin{array}{l}\text { Stages of } \\
\text { implementation } \\
\text { of the project }\end{array}$ & Basic level (BL) & Advanced level (AL) \\
\hline Sketch & $\begin{array}{l}\text { Creating a sketch } \\
\text { The idea of a musical work. Selecting a } \\
\text { video plot. Musical sketches of the main } \\
\text { contour (melodies, accompaniments, } \\
\text { sample instrumentation, the structure of } \\
\text { the work, features of texture, tonal plan, } \\
\text { etc.) } \\
\text { Note text can be created in music } \\
\text { editors (Finale or Sibelius) or } \\
\text { immediately in a sequencer (Sonar, } \\
\text { Steinberg Cubase, etc.). Here, the } \\
\text { material picked up by ear or copied from } \\
\text { the finished parties is used. }\end{array}$ & $\begin{array}{l}\text { Creating a sketch } \\
\text { The idea of a musical work. Selecting a } \\
\text { video plot. Musical sketches of the main } \\
\text { contour (melodies, accompaniments, } \\
\text { sample instrumentation, the structure of } \\
\text { the work, features of texture, tonal plan, } \\
\text { etc.) } \\
\text { Note text can be created in music editors } \\
\text { (Finale or Sibelius) or immediately in a } \\
\text { sequencer (Steinberg Cubase, etc.). Own } \\
\text { compositions created based on specified } \\
\text { parameters or completely independent are } \\
\text { used. }\end{array}$ \\
\hline
\end{tabular}


Table 3 - Creative project in the framework of the discipline "Computer Music"

(continuation)

\begin{tabular}{|c|c|c|}
\hline $\begin{array}{l}\text { Stages of } \\
\text { implementation } \\
\text { of the project }\end{array}$ & Basic level (BL) & Advanced level (AL) \\
\hline $\begin{array}{l}\text { Working with a } \\
\text { sketch in a } \\
\text { music } \\
\text { sequencer }\end{array}$ & $\begin{array}{l}\text { 1. Writing planned parties, adding other } \\
\text { voices, accompaniment. The entire } \\
\text { creative process takes place in a } \\
\text { musical sequencer (Sonar). } \\
\text { 2. Assignment of various instruments } \\
\text { for parts (using the sound bank of the } \\
\text { sequencer itself or additional plug-ins } \\
\text { (Edirol HQ Orchestral and Super } \\
\text { Quartet, Korg Wavestation, etc.). } \\
\text { 3. Placing the dynamic shades of the } \\
\text { main parts in the Piano Roll window } \\
\text { of the music sequencer (Cakewalk } \\
\text { Sonar). }\end{array}$ & $\begin{array}{l}\text { 1. Writing planned parties, adding other } \\
\text { voices, accompaniment. The entire } \\
\text { creative process takes place in a } \\
\text { musical sequencer (Cubase). } \\
\text { 2. Assignment of various instruments for } \\
\text { parties (using the Tascam GigaStudio, } \\
\text { Native Instruments Kontakt, ReFX } \\
\text { Nexus, and other sound libraries). } \\
\text { 3. The arrangement of dynamic shades } \\
\text { and other nuances of the performance } \\
\text { of all parts in the Piano Roll window of } \\
\text { the music sequencer (Cakewalk Sonar). }\end{array}$ \\
\hline $\begin{array}{l}\text { Mixing and } \\
\text { mastering }\end{array}$ & $\begin{array}{l}\text { Mixing and mastering in the music } \\
\text { sequencer } \\
\text { 1. Placing balance, panoramas in the } \\
\text { sequencer program (Sonar). } \\
\text { 2. Work with sound in a music } \\
\text { sequencer (Sonar, Cubase) using } \\
\text { additional plug-ins for mastering (L3 } \\
\text { MultiMaximizer, TrueVerb). }\end{array}$ & $\begin{array}{l}\text { Mixing and mastering in sound processing } \\
\text { programs } \\
\text { 1. Converting from each sequencer } \\
\text { (Cubase) separately each track to audio } \\
\text { files for further work in an audio editor } \\
\text { (Adobe Audition). } \\
\text { 2. Downloading of files pre-converted in } \\
\text { the sequencer to the audio editor Adobe } \\
\text { Audition. } \\
\text { 3. Removing noise and other unnecessary } \\
\text { elements. } \\
\text { 4. Arrangement of tracks in their places } \\
\text { according to the idea of the work. } \\
\text { 5. Arrangement of volume levels of each } \\
\text { part separately. } \\
\text { 6. Adjusting the panning sound of } \\
\text { instruments. } \\
\text { 7. Sound processing of each track } \\
\text { separately. } \\
\text { 8. Creating changes in effect parameters } \\
\text { (height, tempo) over time on individual } \\
\text { tracks or the control track. } \\
\text { 9. Removing sound distortions. } \\
\text { 10. Converting material into a convenient } \\
\text { format for further work in mastering } \\
\text { programs (T-RackS24, IZotope Ozone, } \\
\text { etc.). } \\
\text { Work on sound with a ready-made audio } \\
\text { file in a mastering program (T-RackS24, } \\
\text { IZotope Ozone). }\end{array}$ \\
\hline $\begin{array}{l}\text { Saving the } \\
\text { finished } \\
\text { material }\end{array}$ & $\begin{array}{l}\text { Exporting finished material from a music } \\
\text { sequencer } \\
\text { Export to an audio file of various formats } \\
\text { (wav, mp3, ogg, etc.) }\end{array}$ & $\begin{array}{l}\text { Saving the finished material to the final } \\
\text { audio file } \\
\text { Saving the result in various publicly available } \\
\text { audio formats (wav, } \mathrm{mp3} \text {, ogg, etc.). }\end{array}$ \\
\hline $\begin{array}{l}\text { Working in the } \\
\text { audio editor }\end{array}$ & $\begin{array}{l}\text { Final work on the sound in the audio } \\
\text { editor } \\
\text { Sound normalization in the audio editor } \\
\text { (Sound Forge). }\end{array}$ & $\begin{array}{l}\text { Final work on the sound in the audio editor } \\
\text { Sound normalization in the audio editor } \\
\text { (Adobe Audition). }\end{array}$ \\
\hline
\end{tabular}


Table 3 - Creative project in the framework of the discipline "Computer Music"

(conclusion)

\begin{tabular}{|c|l|l|}
\hline $\begin{array}{c}\text { Stages of } \\
\text { implementation } \\
\text { of the project }\end{array}$ & \multicolumn{1}{|c|}{ Basic level (BL) } & \multicolumn{1}{c|}{ Advanced level (AL) } \\
\hline $\begin{array}{c}\text { Working in the } \\
\text { video editor }\end{array}$ & $\begin{array}{c}\text { Combining audio and video } \\
\text { Overlaying an audio file on a (borrowed) } \\
\text { video using a video editor (TMPGEnc } \\
\text { XPress, Sony Movies Studio Platinum). }\end{array}$ & $\begin{array}{l}\text { Combining audio and video } \\
\text { Overlaying an audio file on a video plot } \\
\text { (borrowed or independently created), } \\
\text { followed by using effects on both the audio } \\
\text { and video file using the video editor (Sony } \\
\text { Vegas, Adobe Premiere Pro, Pinnacle } \\
\text { Studio, etc.). }\end{array}$ \\
\hline $\begin{array}{c}\text { Recording to } \\
\text { external } \\
\text { storage devices }\end{array}$ & $\begin{array}{l}\text { Creating DVD, Blu-ray, etc. disks with } \\
\text { built-in Windows OS tools. }\end{array}$ & $\begin{array}{l}\text { Creating DVD, Blu-ray disks using } \\
\text { specialized software such as Nero Express } \\
\text { or multitrack audio editor Adobe Audition. }\end{array}$ \\
\hline
\end{tabular}

Source: Own elaboration (2020).

Students showed a strong desire to explore further the possibilities of MCT in their professional activities. There has been a qualitative leap in knowledge and skills in the field of IT, as well as in the professional music field. Many of them noted the need for self-education and further participation in the creation of musical creative projects implemented under the conditions of the functioning of a high-tech information educational environment. The results of own creative work of students found their application in the participation of many musical projects for scoring films, cartoons, performances, web sites, computer games, including Farm Mania 2. (Mind Ocean Studio, Realore Studios), Pharaoh's Secrets (Thunderstorm Games, Real Arcade), King's Bounty: The Legend of the Knight (Katauri, 1C), etc.

\section{Conclusion}

The musical education of the 21st century needs a new concept that involves the realities of today: activation of creative forms of work using MCT, in particular, tools for computer musical creativity. At the same time, the modern areas of music education shall not separate from the cultural traditions of the inherited artistic interpretation of reality; maintain a high spiritual and moral level of the process of teaching creativity.

The developed methodology for teaching computer science and IT combines the directions of the high-tech information educational environment and the music fields, which contributes to the creation of a special educational environment in which the learning process broadens the horizons of students, increases the professional level, 
and, most importantly, develops the productive creative consciousness that is so necessary for a modern music teacher. The authors emphasize that the stages of work on the project affect not only the topics of the professional musical sphere but also the field of IT, revealing them optimally and conveniently for students following the specifics of their professional activity.

The use of project activities in training in the context of the functioning of modern high-tech information educational environments is becoming increasingly relevant. Using the project method, it is possible to implement effectively many significant educational, educational and developmental tasks that allow us to fruitfully form the informational and professional competence of students of musical and pedagogical specialties, integrate various types of activities, making the learning process more fun, interesting and therefore more effective.

\section{References}

ALIEVA, I. G.; GORBUNOVA, I. B.; MEZENTSEVA, S. V. Music Computer Technologies as a tool for broadcasting and preserving musical folklore (using the example of the Russian Far East). Music Scholarship, v. 34, n. 1, p. 140-149, 2019a. DOI: 10.17674/1997-0854.2019.1.140-149.

ALIEVA, I. G.; GORBUNOVA, I. B.; MEZENTSEVA, S. V. Music Computer Technologies as a worth-while means of folklore studying, preserving and transmission. Utopía y Praxis Latinoamericana, Maracaibo, v. 24, n. S6, p. 118-131, 2019 b.

BELLO, C. C. ¿De dónde venimos y hacia dónde vamos? Reflexiones y experiencias de vida de una pianista cubana. In: GORBUNOVA, I. B. (Ed.). Contemporary Musical Education - 2014. Proceedings of the 13th International Research and Practical Conference. St. Petersburg, 2014. p. 163-167.

BELOV, G. G.; GORBUNOVA, I. B. Cybernetics and music: problem statement. Society: Philosophy, History, Culture, n. 12, p. 138-143, 2016.

CHAO-FERNÁNDEZ, R.; ROMÁN-GARCÍA, S.; CHAO-FERNÁNDEZ, A. Analysis of the use of ICT through music interactive games as an educational strategy. In: 7th International Conference on Intercultural Education - Education, Health and ICT - From a Transcultural Perspective, Procedia Social and Behavioral Sciences, Almería, v. 237, p. $576-580,2017$. 
COLIN, K. K. The formation of informatics as fundamental science and a complex scientific problem. Systems and means of informatics, Special Issue Scientific and methodological problems of computer science, p. 7-58, 2006.

CRAWFORD, R.; SOUTHCOTT, J. Curriculum stasis: the disconnect between music and technology in the Australian curriculum. Technology Pedagogy and Education, v. 26, n. 3, p. 347-366, 2017.

ERASMO, C. P. G. El Efecto Mozart Visual e Interactiva en los Pianos Casio. In: GORBUNOVA, I. B. (Ed.). Contemporary Musical Education - 2015. Proceedings of the 14th International Research and Practical Conference. St. Petersburg, 2015. p. 260-262.

ESPERÓN, L. G. Reflexiones de una niña sin oido y desafinada. In: GORBUNOVA, I. B. (Ed.). Contemporary Musical Education - 2018. Proceedings of the 17th International Research and Practical Conference. St. Petersburg, 2018. p. 125-127.

GOH, K. M. Moving toddlers and parents with MCT in Asia. In: GORBUNOVA, I. B. (Ed.). Contemporary Musical Education - 2016. Proceedings of the 15th International Research and Practical Conference. St. Petersburg, 2016. p. 137-141.

GORBUNOVA, I. B. Electronic Musical Instruments: to the Problem of Formation of Performance Mastery. 16th International Conference on Literature, Languages, Humanities \& Social Sciences (LLHSS-18). Int'I Conference Proceedings, 2018a. p. 1519. DOI: https://doi.org/10.17758/uruae4.uh10184023.

GORBUNOVA, I. B. Music Computer Technologies in the Perspective of Digital Humanities, Arts, and Researches. Opción, v. 35, n. S24, p. 360-375, 2019.

GORBUNOVA, I. B. New Tool for a Musician. International Conference Proceedings. Icaset-18, ASBES-18, EEHIS-18 International Conference Proceedings, 2018b. p. 144149. DOI: 10.17758/uruae2.ae06184024.

GORBUNOVA, I. B.; CHIBIREV, S. V. Modeling the Process of Musical Creativity in Musical Instrument Digital Interface Format. Opción, v. 35, n. S22, p. 392-409, 2019.

GORBUNOVA, I. B.; GOVOROVA, A. Music Computer Technologies in Informatics and Music Studies at Schools for Children with Deep Visual Impairments: from the experience. Lecture Notes in Computer Science Proceedings, v. 11169, p. 381-389, 2018. DOI: https://doi.org/10.1007/978-3-030-02750-629.

GORBUNOVA, I. B.; HINER, H. Music Computer Technologies and Interactive Systems of Education in Digital Age School. Proceedings of the International Conference Communicative Strategies of Information Society (CSIS 2018), 2019. p. 124-128. DOI: https://doi.org/10.2991/csis-18.2019.25. 
GORBUNOVA, I. B.; KAMERIS, A. Music Computer Education Concept for Teachers: Raising the Problem. International Journal of Recent Technology and Engineering, v. 8, n. 2 S4, p. 913-918, 2019. DOI: 10.35940/ijrte.B1181.0782S419.

GORBUNOVA, I. B.; KAMERIS, A.; BAZHUKOVA, E. N. Musical Informatics Course for Musicians with Using Music Computer Technologies. International Journal of Recent Technology and Engineering, v. 8, n. 6, p. 3040-3045, 2020.

GORBUNOVA, I. B.; KIBITKINA, E. V. Music programming: issues of preparing specialists. Art and Education, v. 5, n. 67, p. 104-111, 2010.

GORBUNOVA, I. B.; PETROVA, N. N. Music Computer Technologies, Supply Chain Strategy and Transformation Processes in Socio-Cultural Paradigm of Performing Art: Using Digital Button Accordion. International Journal of Supply Chain Management, v. 8, n. 6, p. 436-445, 2019.

GORBUNOVA, I. B.; PLOTNIKOV, K. Y. Music-Related Educational Project for Contemporary General Music Education of Schoolchildren. International Journal of Innovation, Creativity, and Change, v. 9, n. 13, p. 683-699, 2019.

GORBUNOVA, I. B.; ZALIVADNY, M. S. Leonhard Euler's Theory of Music: Its PresentDay Significance and Influence on Certain Fields of Musical Thought. Music Scholarship, v. 3, n. 36, p. 104-111, 2019. DOI: 10.17674/1997-0854.2019.3.104-111.

GORBUNOVA, I. B.; ZALIVADNY, M. S. The Integrative Model for the Semantic Space of Music: Perspectives of Unifying Musicology and Musical Education. Music Scholarship, v. 4, 55-64. 2018. DOI: 10.17674/1997-0854.2018.4.055-064.

HASTINGS, K. Anybody Can Play Soft Mozart in the Preschool: Learning to Learn Properly to Develop the Brain. In: GORBUNOVA, I. B. (Ed.). Contemporary Musical Education - 2014. Proceedings of the 13th International Research and Practical Conference. St. Petersburg, 2018. p. 160-165.

HORITA, T. Trend and problems of informatization at school education. Japanese Journal of Music Education Practice, v. 11, n. 2, p. 6-13, 2014.

KING, A.; HIMONIDES, E.; RUTHMANN, S. A. (Ed.). The Routledge Companion to Music, Technology, and Education. New York and London: 10017, 2017.

LOZHAKOVA, E. A. Forming informational competence of future musicians in the process of teaching computer science bachelors. Dissertation of the Candidate of Pedagogical Sciences, Moscow, 2012.

NELIA, O.; BEAN, H. Efecto, Modernidad y Creación. In: GORBUNOVA, I. B. (Ed.). Contemporary Musical Education - 2014. Proceedings of the 13th International Research and Practical Conference. St. Petersburg, 2014. p. 123-125. 
PERMEZEL, T. Dispelling the myth of the exclusivity of musical literacy. In:

GORBUNOVA, I. B. (Ed.). Contemporary Musical Education - 2014. Proceedings of the 13th International Research and Practical Conference. St. Petersburg, 2014. p. 163-167.

PRIGOGINE, I. The Die Is Not Cast. Futures: Bulletin of the World Futures Studies Federation, v. 25, n. 4, p. 17-19, 2000.

RADIF, M.; MOHAMMED, N. A. Computer Science Teacher's Perception and Needs towards E-Learning in Iraq. Journal of Southwest Jiaotong University, v. 54, n. 5, 2019. Available at: http://jsju.org/index.php/journal/article/view/412. Accessed on: Apr. 10, 2020.

SERGEEVA, M. G. et al. Building a Professional Career of a University Teacher Based on the Information Engineering. Journal of Southwest Jiaotong University, v. 54, n. 6, 2019. Available at: http://jsju.org/index.php/journal/article/view/483. Accessed on: Apr. 10, 2020

SOSNEVAS, S. Arten der Musikausbildung in Deutschland - Der Blick einer zertifizierten Soft Mozart Klavierlehrerin aus Berlin. In: GORBUNOVA, I. B. (Ed.). Contemporary Musical Education - 2018. Proceedings of the 17th International Research and Practical Conference. St. Petersburg, 2018. p. 235-238.

WISE, S. Secondary school teachers' approaches to teaching composition using digital technology. British Journal of Music Education, v. 33, n. 3, p. 283-295, 2016.

ZHILYAEVA, N. Classes in music with children of various ages at home as an alternative to a music school in the USA. In: GORBUNOVA, I. B. (Ed.). Contemporary Musical Education - 2014. Proceedings of the 13th International Research and Practical Conference. St. Petersburg, 2014. p. 137-141.

\footnotetext{
Irina Borisovna Gorbunova, Herzen Russian State Pedagogical University, Department of Digital Education, Institute of Information Technologies and Technological Education

iDhttps://orcid.org/0000-0001-8406-0665

Professor of the Department of Digital Education of the Institute of Information Technologies and Technological Education, Head and Chief Researcher of the Education and Methods Laboratory Music Computer Technologies at the Herzen State Pedagogical University of Russia, St. Petersburg, Russia. Authorship contribution: Main conception and general lines of the main ideas of the article, as well as the development of a course cycle of the course "Information Technology in Music".

E-mail: gorbunova7575@yandex.ru
}

\footnotetext{
Anastasia Anatolyevna Pankova, Herzen Russian State Pedagogical University, Department of Education and Music Laboratory Methods, Computer Technologies

ii:Dhttps://orcid.org/0000-0002-8029-5464

$\mathrm{PhD}$ in Pedagogy, Senior Researcher of the Education and Methods Laboratory Music Computer Technologies at the Herzen State Pedagogical University of Russia, St. Petersburg, Russia.

Authorship contribution: Description of the work steps in creating a creative project when teaching students about the cycle called disciplines.

E-mail: a.a.pankova@bk.ru
} 
Responsible publisher: Lia Machado Fiuza Fialho

Ad hoc experts: Angélica Silva and Karla Angélica Silva do Nascimento

\section{How to cite this article (ABNT):}

GORBUNOVA, Irina Borisovna; PANKOVA, Anastasia Anatolyevna. Teaching Computer Science and Information Technology Studies for students of musical and pedagogical specialties. Educ. Form., Fortaleza, v. 5, n. 3, p. 1-17, 2020. Available at:

https://revistas.uece.br/index.php/redufor/article/view/3350.

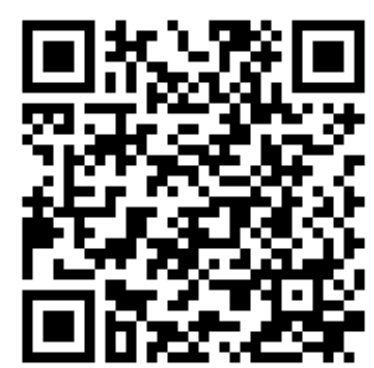

Received on June $1^{\text {st }}, 2020$.

Accepted on June $14^{\text {th }}, 2020$.

Published on July $26^{\text {th }}, 2020$. 